This article was downloaded by: [K.U.Leuven - Tijdschriften]

On: 09 September 2011, At: 11:16

Publisher: Routledge

Informa Ltd Registered in England and Wales Registered Number: 1072954

Registered office: Mortimer House, 37-41 Mortimer Street, London W1T 3J H, UK

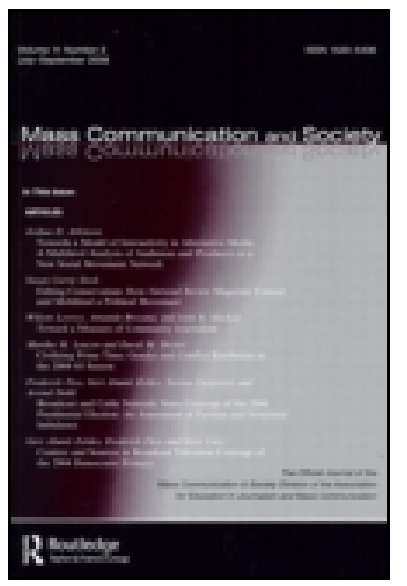

\title{
Mass Communication and Society
}

Publication details, including instructions for authors and subscription information:

http:// www. tandfonline.com/loi/ hmcs20

\section{Television and Political Participation Among Adolescents: The Impact of Television Viewing,} Entertainment and Information Preferences

\author{
Ellen Quintelier ${ }^{a} \&$ Marc Hooghe ${ }^{a}$ \\ ${ }^{a}$ Department of Political Science, Katholieke \\ Universiteit Leuven
}

Available online: 09 Sep 2011

To cite this article: Ellen Quintelier \& Marc Hooghe (2011): Television and Political Participation Among Adolescents: The Impact of Television Viewing, Entertainment and Information Preferences, Mass Communication and Society, 14:5, 620-642

To link to this article: http:// dx.doi.org/ 10.1080/ 15205436.2010.530383

PLEASE SCROLL DOWN FOR ARTICLE

Full terms and conditions of use: http://www.tandfonline.com/page/termsand-conditions

This article may be used for research, teaching and private study purposes. Any substantial or systematic reproduction, re-distribution, re-selling, loan, sub-licensing, systematic supply or distribution in any form to anyone is expressly forbidden. 
The publisher does not give any warranty express or implied or make any representation that the contents will be complete or accurate or up to date. The accuracy of any instructions, formulae and drug doses should be independently verified with primary sources. The publisher shall not be liable for any loss, actions, claims, proceedings, demand or costs or damages whatsoever or howsoever caused arising directly or indirectly in connection with or arising out of the use of this material. 


\title{
Television and Political Participation Among Adolescents: The Impact of Television Viewing, Entertainment and Information Preferences
}

\author{
Ellen Quintelier and Marc Hooghe \\ Department of Political Science \\ Katholieke Universiteit Leuven
}

\begin{abstract}
Although sweeping statements about the effect of television viewing on political participation could still be found in the literature in the 1990s, it is now commonly held that the effect of television should be studied as a multidimensional phenomenon. Not only the time spent watching television but also the kinds of programs being watched and even the preference for particular stations are assumed to have an effect. In this article, we report on a survey among 6,330 Belgian adolescents allowing for a comprehensive analysis of the relationship between various dimensions of television viewing and political participation. We focus on adolescents, because research suggests that the decline in participation levels clearly manifests itself in this age group. The results of the analysis confirm a negative impact of the amount of television viewing, which is partly counterbalanced by a positive impact of a preference for information and for public broadcasting. We discuss the implications of these findings among adolescents for adult participation behavior.
\end{abstract}

Ellen Quintelier (Ph.D., Katholieke Universiteit Leuven, 2009) is a Postdoctoral Researcher of the FWO Research Foundation at the Centre for Political Science at Katholieke Universiteit Leuven. Her research interests include political psychology, particularly youth sociology.

Marc Hooghe (Ph.D., University of Brussels, 1997; Ph.D., University of Rotterdam, 2002) is a Professor in the Department of Political Science at Katholieke Universiteit Leuven. His research interests include social capital and political participation and the transformation of voluntary associations and political parties.

Correspondence should be addressed to Marc Hooghe, Department of Political Science, Katholieke Universiteit Leuven, Parkstreet 45, Box 3602, Leuven 3000, Belgium. E-mail: marc.hooghe@soc.kuleuven.be 


\section{INTRODUCTION}

The impact of television on political participation has been a matter of recurrent concern within communication research. During the 1990s, this debate was still conducted in very broad terms, with various publications depicting a stereotypical view of a new generation of "couch potatoes" (Cappella \& Jamieson, 1997; Patterson, 1993; Postman, 1985; Putnam, 2000). In subsequent research, however, this gloomy picture has been greatly modified. The uses and gratification approach suggests that audiences actively select the media content they are exposed to, which implies that rather than expecting general media effects, attention should be focused on specific media contents (Vincent \& Basil, 1997). The available research results are indeed far from conclusive.

First, the negative relationship between the amount of time television viewing and political participation levels has not been confirmed by all available studies, and a number of authors even detect a positive relationship between participation levels and certain types of programs (Hoffman \& Thomson, 2009; Livingstone \& Markham, 2008).

Second, a number of authors have also argued that the effects of television are dependent on various dimensions of the phenomenon (Moy, McCluskey, McCoy, \& Spratt, 2004; Pasek, Kenski, Romer, \& Jamieson, 2006). Within the uses and gratifications approach, researchers have introduced a distinction between the entertainment and information function of television use (Rubin, 1983). Building on this distinction, Prior (2005, 2007) argued that the entertainment use of television is negatively associated with political knowledge and political participation, whereas the opposite relationship is observed for the information function of television. This uses and gratifications approach toward the study of television effects has gained salience as a result of the emergence of high-choice media environments. Given that the choices available to media consumers have multiplied during the past decades, it can be assumed that the differentiation of television effects has increased accordingly (Prior, 2007). The range of media options available allows viewers to make an effective selection, resulting in a closer fit between their prior motivations and their actual viewing behavior.

Third, not just the types of programs being watched can be expected to differentiate television effects, but the different broadcast stations too may cultivate specific political orientations, as their aim is to encourage station loyalty among potential viewers. The habit of watching specific channels could therefore be related to specific value orientations among a particular group, even controlling for program content (Mendelsohn \& Nadeau, 1996). Television networks try to promote brand loyalty among their viewers, which might lead to the development of habitual viewing behaviors among 
specific audience groups (Eastman \& Ferguson, 1997). In various European countries with a strong public broadcasting tradition, differences have been documented between the relative effects of regularly viewing public or commercial broadcasting (Holtz-Bacha \& Norris, 2001; Jenssen, 2009; Schmitt-Beck, 2008).

What is missing thus far in the literature is a comprehensive account of these various dimensions of television effects: If we simultaneously consider the time spent on television, the types of programs watched, and the preferences for specific channels, what is the overall picture that emerges? Does the inclusion of a measure for viewers' preference for entertainment imply that television viewing as such (as a general measure) no longer has a significant effect on participation levels? In the current high-choice media environment, we should no longer expect the occurrence of general media effects, but we should focus on content-specific and station-specific effects, as audiences expose themselves to specific media contents. The process of "interest maximation" allows viewers to achieve a close fit between their preferences and actual viewing behavior (Jeffres, 1978).

In this article, we develop a comprehensive account of the effects of various dimensions of television viewing behavior on political participation by analyzing data from a representative sample of adolescents in Belgium. Our contribution to the debate lies in the simultaneous inclusion of all theoretically relevant variables, which allows us to assess whether it makes sense to distinguish between these various components of television viewing. We focus on adolescents because media effects can be expected to be stronger in this age group than among adult audiences (Arnett, 1995). Furthermore, various studies have shown that the decline of participation levels in Western democracies is concentrated among younger age cohorts (Kimberlee, 2002; Li \& Marsh, 2008; O’Toole, Lister, Marsh, Jones, \& McDonagh, 2003; Wattenberg, 2007). Belgium offers a good case study because of the strong presence of a public broadcasting system, ${ }^{1}$ allowing us to distinguish between the effects of commercial and public broadcasting (Jenssen, 2009).

In the remainder of this article we briefly review the literature on the relationship between television viewing and political participation. The review of the literature is structured on the three major issues we distinguished: time, programs, and channels. Next, we present the data, methods, and the operationalization of the variables. The results of a regression

\footnotetext{
${ }^{1}$ Both in the Dutch-speaking and the French-speaking community of the country, the two public broadcasting corporations (VRT and RTBF, respectively) enjoy a solid market share, although this is larger in the Dutch community than in the French community.
} 
analysis are then presented, followed by discussion of the relevance of these findings.

\section{REVIEW OF THE LITERATURE}

\section{Time Effects}

Concern about the alleged negative impact of television on political participation is certainly not a new phenomenon (Moy, Scheufele, \& Holbert, 1999; Putnam, 2000). The main claim in this line of research was that the increasing amount of time spent on television viewing and other media reduces the time available for participation. The negative relationship between the time spent in front of the television and the time spent on participation has often been considered as a time-replacement effect: It was taken that the time that is now being spent in front of the television set is no longer available for social activities, although it should be noted that other causal mechanisms might be involved as well. Thus, television viewing may be associated with a lack of mental and behavioral involvement in the local community. Heavy television viewers, it has been claimed, have a weaker sense of belonging to a specific community and feel less efficacious in changing living conditions within their group (Uslaner, 1998).

\section{Program Preferences}

Markus Prior $(2005,2007)$, in particular, has argued that these general and sweeping statements about the effect of television might have become obsolete. In recent decades, the television market has changed dramatically, offering viewers a growing array of options. As Prior (2005) argued, this might imply that some earlier findings about television and political participation are no longer valid:

As media choice increases, content preferences thus become the key to understanding political learning and participation. In a high-choice environment, politics constantly competes with entertainment. Until recently, the impact of content preferences was limited because media users did not enjoy much choice between different content. (p. 577)

In the past, this limited choice meant that viewers were not always able to self-select exposure to specific types of programming. Due to programming practices, even viewers interested in sitcoms were almost inevitably exposed to news and current affairs programs. In the current high-choice media 
environment, however, choice and self-selection play a much greater role, allowing viewers to select specific forms of media content to a much greater extent than was the case when the uses and gratifications approach was first developed in the literature. In his own study, Prior (2007, p. 35) demonstrated that, whereas in a low-choice television environment some $80 \%$ of all viewers watch at least some news broadcast items, this is only $42 \%$ in a high-choice environment. Not only have broadcasters fine-tuned their programming strategies, serving specific niche audiences, but most households now also have access to many more channels than ever before (Chaffee \& Frank, 1996). In a "high-choice media environment," viewers can easily avoid political information, and therefore the least interested are the most likely to avoid political programs. This evolution makes it even more unlikely that general media effects will be found, as various audience segments can and do have totally different television viewing preferences and motivations (Ruggiero, 2000).

Some earlier studies have already demonstrated that the use of television for either entertainment or information may lead to widely divergent outcomes with regard to political participation. Not differentiating between both preferences entails the risk of opposing effects canceling each other out, leading to a nonconclusion. In most of the literature, it has indeed been demonstrated that the use of mass media for information is associated with higher levels of participation, whereas the opposite is true for the entertainment use (Holtz-Bacha, 1990; Y. M. Kim \& Vishak, 2008; Putnam, 2000; Sotirovic \& McLeod, 2001; Zhang \& Chia, 2006). Newton (1999) argued that watching films leads to a decreased level of political knowledge and political interest. Hooghe (2002) similarly concluded that movies and soaps (i.e., entertainment programs) do not have an effect on political efficacy. On the other hand, Norris and other authors found that watching television news raises the level of political knowledge, civic and political participation, interest, social trust, and efficacy (Ho et al., 2011; E. Kim, Scheufele, \& Han, 2011; Norris, 1996, 2000a, 2000b; Shah, McLeod, \& Yoon, 2001; Zhang \& Chia, 2006). Newton (1999) confirmed that watching television news increased political knowledge, political interest, and the feeling that democracy works. In line with these findings, Prior (2007) demonstrated that watching television news is associated with greater political knowledge, interest, and higher voter turnout, especially among the less educated. Jung, Kim, and Homero (2011), finally, have shown that the use of news media spurs political participation, and this positive effect is mediated by political discussion, online political messaging, political knowledge, and efficacy.

In other research, it has been shown that some programs are more likely to induce a perception of a "mean world" than others (Uslaner, 1998). Reality programs, for instance, are associated with social mistrust and civic 
disengagement (Gerbner, Gross, Morgan, \& Signorielli, 1980; Shah, McLeod, \& Yoon, 2001).

\section{Television Stations}

Not only program preferences, however, but also the choice of specific television stations may have a mitigating effect. The types of studies just mentioned have mainly been conducted in a European context, where public broadcasting accounts for a large share of the total audience. Findings suggest that a preference for public broadcasting is associated with higher levels of political knowledge and political efficacy, whereas the opposite is true for watching commercial stations (Blumler \& Hoffmann-Riem, 1992; De Vreese \& Boomgaarden, 2006; Holtz-Bacha \& Norris, 2001). Other authors, however, are much more skeptical about the question whether viewers tend to stick to one channel or just browse channels (Morris \& Forgette, 2007). On the precise reason for the occurrence of these opposite effects, however, opinions continue to differ (Aarts \& Semetko, 2003). Some authors argue that commercial television is likely to be associated with lower quality programming, as investment is driven by market imperatives (Holtz-Bacha \& Norris, 2001; Milner, 2005). It can also be assumed that commercial stations will devote less airtime to information programs than public broadcast stations do, but even controlling for program content, the effect of the station itself seems to remain significant in some of the available research (Aarts \& Semetko, 2003; Hooghe, 2002).

\section{Goal of the Study}

It is important to disentangle the various dimensions of television-viewing behavior, as this may provide more specific clues about the underlying causal mechanisms. If time was found to be the most important element, some form of time-replacement effect might be at work. If programs or program preferences proved to be of paramount importance, it would be obvious that selective exposure and program content might play a role. Finally, if station preferences are found to be important, some form of group processes, habits, and cultivation might seem an obvious focus for future research. Correct assessment of the various dimensions of television viewing is therefore crucial, which implies that all these elements must be included in one multivariate model.

Although concern about the impact of television on political participation is quite general, and can be applied to the television audience as a whole, younger age cohorts receive special attention in this line of study. As Pasek et al. (2006) showed, political participation levels are typically very 
low for this age group, and young people score poorly on various indicators of political participation. Simultaneously, we also know that media consumption tends to be quite high for this age group (Arnett, 1995; Livingstone, 2002; Morris \& Forgette, 2007). As young people have had fewer previous socialization experiences, media effects can be expected to be strongest among this age group (Livingstone, 2002). Austin, Van de Vord, Pinkleton, and Epstein (2008) have shown that celebrity-endorsed, get-outthe-vote campaigns are associated with higher levels of political efficacy among young voters. Studying youth participation patterns is also important because previous research has established that participation is a habit that is picked up quite early in the life cycle. Individuals already active during adolescence are more likely to continue this practice throughout the life cycle (Jennings \& Stoker, 2004). This makes it all the more relevant to study engagement patterns at an early age.

In this article, we focus on the effect of selective exposure in the current high-choice television environment on the political participation habits of late adolescents. Self-evidently, the Internet is rapidly becoming the preferred communication channel of adolescents (Quintelier \& Vissers, 2008) and probably will overtake television as the main source of information about the outside world in the near future. For the time being, however, television remains a very important, if not the main, mass communication tool for adolescents (Hoffman \& Thomson, 2009, p. 6).

\section{HYPOTHESES}

Given the findings in the research literature, one can expect a negative relationship between the time spent watching television and levels of political participation (H1). Second (H2), it is hypothesized that a preference for entertainment programs is associated with low participation levels, whereas this is not the case for information programs. The third hypothesis (H3) suggests that public television has a more positive effect on political engagement than commercial stations. Unlike the previous literature, this article aims to incorporate all three dimensions of television viewing simultaneously, thus allowing for proper assessment of the three hypotheses.

\section{DATA AND METHODS}

These hypotheses are tested using the results of the Belgian Youth Survey 2006 (BYS 2006), which was conducted among 6,330 fifteen- and 
sixteen-year-olds in Belgium. A response analysis showed that the survey results are representative for 16-year-olds in Belgium, with no significant differences with regard to gender, region, language, ethnic origin, education level, and school track. Because schooling is compulsory until the age of 18 in Belgium, this means that the sample is also representative for the entire population of 16-year-old adolescents (Hooghe, Quintelier, Claes, \& Dejaeghere, 2006). Based on written questionnaires completed by the respondents in 112 schools, the study focuses on young people's social and political attitudes and contains questions about how much time they spend watching television, what kinds of programs they watch, and which channels they prefer. As such, this data set is ideally suited to test the three hypotheses.

It should also be noted that Belgian legislation does not require prior written consent from the parents for this kind of research, which renders it easier to obtain a representative sample of adolescents. In countries requiring prior written parental consent, on the other hand, response rates among adolescents can be as low as 3.2\% (Hoffman \& Thomson, 2009, p. 11). The high response rate renders it more likely that the answers obtained in this survey are indeed representative for this age group in Belgium. In the following paragraphs, we first present the most important variables in the analysis.

\section{Television Viewing}

If we want to ascertain the effects of various components of television-watching behavior, it is crucial that all of them are adequately measured (Prior, 2009a, 2009b). Hence, the questionnaire included elaborate measurements of television viewing. First, respondents were asked about the time they spent watching television. Answer options ranged from (a) never watch television, (b) watch less than 1 hour, (c) 1 to 2 hours, (d) 3 to 4 hours, to (e) 5 and more hours per day. Second, entertainment and information preferences were measured. This was done by presenting respondents with a list of 12 types of television programs from which they could select up to 3 favorite programs: music videos, reality $\mathrm{TV}$, cartoons, movies, youth programs, soaps, talk shows, news and current events, game shows, programs about their community, lifestyle programs, or sports programs. The answers were used to construct entertainment and information preferences scales (see next). Third, respondents were presented with a list of 18 different television stations that are offered on most local cable networks in the country. Again, respondents could select up to three favorite networks. 


\section{Political Participation}

The dependent variable in the analysis is political participation: To what extent do adolescents participate in the political life of their communities? We rely on the standard definition of political participation as any act that is performed with intention of transmitting information about social preferences and issues to political decision makers and exerting pressure on these decision makers to pay attention to the demands being voiced (Milbrath, 1965; Rosenstone \& Hansen, 1993; Verba \& Nie, 1972; Verba, Schlozman, $\&$ Brady, 1995). Within normative political theory, there is a general consensus that political participation is an important element of a democratic political culture (Dalton, 2005). In total, respondents were presented with 10 different activities that they could have participated in during the previous 12 months, ranging from boycotting products for political or ethical reasons to forwarding e-mails with political content and the frequency of those activities was recorded (never, a few times, often; see Table 1 for question topics). It has to be noted that voting - the most common political participation act-is not included in this list, as 16-year-olds do not have the right to vote in Belgium. Within the literature on youth participation, it is customary to make a distinction between a more narrow definition of participation, tied to the functioning of political institutions on one hand, and more

TABLE 1

Factor Analysis of Political Participation Acts

\begin{tabular}{lccc}
\hline & \multicolumn{3}{c}{ Political participation acts } \\
\cline { 2 - 4 } & $\begin{array}{c}\text { Political } \\
\text { engagement }\end{array}$ & $\begin{array}{c}\text { Political } \\
\text { consumerism }\end{array}$ & $\begin{array}{c}\text { Social movement } \\
\text { engagement }\end{array}$ \\
\hline Contacting politicians & $\mathbf{0 . 6 5 1}$ & -0.050 & 0.021 \\
Displaying messages & $\mathbf{0 . 6 1 1}$ & 0.191 & -0.121 \\
Being a member of a political party & $\mathbf{0 . 5 7 8}$ & -0.202 & -0.003 \\
Forwarding political emails & $\mathbf{0 . 5 4 4}$ & 0.174 & -0.002 \\
Attending a show with political content & $\mathbf{0 . 4 1 7}$ & -0.010 & 0.229 \\
Boycotting & -0.013 & $\mathbf{0 . 8 4 4}$ & 0.015 \\
Buycotting & 0.010 & $\mathbf{0 . 8 4 0}$ & 0.018 \\
Donating/collecting money & -0.186 & 0.088 & $\mathbf{0 . 7 4 0}$ \\
Signing petitions & 0.051 & 0.048 & $\mathbf{0 . 6 6 4}$ \\
Protesting & 0.184 & -0.113 & $\mathbf{0 . 6 0 4}$ \\
Eigenvalues & 2.438 & 1.183 & 1.067 \\
Explained variance & 24.384 & 11.834 & 10.666 \\
\hline
\end{tabular}

Note. Principal component analysis, Promax rotation with Kaiser normalization. Bold represents factor loading greater than 0.40. Source: Belgian Youth Survey 2006 (Hooghe et al., 2006), $n=6,330$. 
social-movement-oriented forms of engagement, on the other hand (Hess \& Torney, 1967; Milbrath, 1965; Torney-Purta, Barber, \& Richardson, 2004). ${ }^{2}$ Other authors have argued that political consumerism should be regarded as a distinct form of engagement that furthermore is accessible to this age group (Stolle, Hooghe, \& Micheletti, 2005). It is important to make the distinction between these three forms of participation, because a number of studies suggest that the decline in institutional political participation among young age groups does not seem to affect social movement-oriented forms of engagement (Zukin et al., 2006). These theoretical distinctions are also included in the factor analysis based on the 10 participation items.

Table 1 presents the results of a factor analysis of the data. Promax rotation has been used as this technique allows for correlated (oblique) dimensions that are typically found in participation behavior (Verba \& Nie, 1972). As Milbrath (1965) and others have shown, political participation is highly cumulative: People who engage in one form of political participation (e.g., voting) are also more likely to engage in other forms (e.g., party membership). Together, these items clearly refer to the standard definition of political participation, but the different components are in line with the expectations generated by the theoretical literature. The first factor consists of actions such as contacting politicians, displaying messages, and being a member of a political party. Although this factor is clearly related to institutional politics, it is not clear whether all the items loading on this factor unequivocally refer to institutional participation, and therefore we have labeled this first factor "political engagement" (to distinguish it from the overall battery of "political participation," including all 10 items). The second factor includes elements of "political consumerism," such as deliberately buying or boycotting products and services for political or ethical reasons. The third "social-movement-engagement" factor contains activities such as donating money, signing a petition, and protesting, which the literature suggests are usually undertaken outside the context of institutionalized politics (Torney-Purta et al., 2004).

\section{Control Variables}

It can be expected that both the dependent and the independent variables in this analysis will be influenced by various background characteristics of the respondents, which are therefore included as control variables (Parry,

\footnotetext{
${ }^{2}$ Torney-Purta et al. (2001) provided a strong case for including these social movement-oriented acts in a definition of political participation, as these clearly aim to change social conditions. As this issue is beyond the scope of this article, we simply note that we follow the approach taken by Torney-Purta et al. (2001).
} 
Moyser, \& Day, 1992; Verba et al., 1995). First, there is a strong relation between socioeconomic status and television watching (Larson, 2001; Newton, 1999). Operationalizing socioeconomic status among adolescents, however, is not a straightforward task, as many adolescents cannot provide a reliable estimate of their parents' income level, and sometimes not even of their education level or their exact professional status. In line with previous research on adolescents, we opted for a combination of two proxy variables (Torney-Purta, Lehmann, Oswald, \& Schulz, 2001). On one hand, respondents could indicate how long they intend to pursue further education. The assumption here is that the expectation of pursuing higher education not only reflects academic capabilities but also serves as a proxy variable for the socioeconomic status of the family of origin. On the other hand, we included information on the number of books at home, a question that is routinely used in the leading international youth surveys as a proxy variable for the family's educational level and socioeconomic background (e.g., Fuchs \& Wößmann, 2007). In the Belgian context, this assessment can still be assumed to reflect a form of cultural capital in the parental household. Both indicators correlate with one another $(r=.260, p<.001)$, and therefore they could be combined in one factor score. Gender is an obvious control variable, as it has an effect on both engagement levels and television viewing (Larson, 2001). Citizenship status was taken into account, as some forms of participation are not easily accessible to those who do not have Belgian nationality (as was the case for $6.3 \%$ of the sample). Political interest increases the likelihood of watching information programs on television and of being politically engaged (Prior, 2007, p. 26; Zukin et al., 2006). A standard political interest question $($ range $=1-4)$ was therefore included in the questionnaire. Political knowledge, too, could serve as a mediating factor, as this can be viewed as a prerequisite for a number of forms of engagement (Delli Carpini \& Keeter, 1996). Knowledge was measured by including four specific questions on politics ${ }^{3}$ and by adding the correct scores.

\section{Method}

Because the dependent variables in this analysis are continuous, ordinary least square multivariate regression techniques were called for. The three forms of engagement were used as dependent variables, whereas three types of television watching behavior (time, programs, and stations) serve as independent

\footnotetext{
${ }^{3}$ Questions included, "Who is the president of the European Commission?" (José Manuel Barosso); "What parts does the Belgian federal parliament consist of?" (Chamber and Senate); "Who is the minister of Justice?" (Laurette Onkelinx); "To which party does Guy Verhofstadt belong?" (VLD). Scores of $0=40.9 \%, 1=29.2 \%, 2=16.2 \%, 3=9.6 \%$, and $4=4.1 \%$.
} 
variables. Given the construction of our theoretical model, we use a stepwise regression model, first including time spent on viewing television, adding subsequently the program preference and in a third step the station being preferred. The rise in explained variance for the three models allows us to ascertain whether including these variables indeed contributes to our understanding of the relation between television and political participation acts.

\section{The Belgian Case}

The data set offers representative information about Belgian adolescents. The Belgian case is particularly apt for the purposes of this study, as the information function of television still plays a prominent role in Belgium. The percentage of people watching the evening news has grown over the last 10 years: In 1997, about $20 \%$ of Belgian citizens watched the news every evening, and by 2007 this figure had risen to $23.6 \%$ (Aalberg, Van Aelst, \& Curran, 2010). Belgium is also a very densely populated country, and since the 1970 s, cable television has been available to more than $90 \%$ of the population, which partly explains why the use of satellite television remains limited and is heavily concentrated among ethnic minorities. For research purposes, this means we know that a vast majority of viewers use cable, which makes it easier to compile a comprehensive list of the programs and channels available to the respondents.

\section{RESULTS}

\section{Watching Television}

A first observation is that adolescents in Belgium spend a substantial amount of time watching television. Despite the rise in Internet use, television is apparently still an essential component of Belgian adolescents' leisure activities (Table 2). Just over one third of all respondents report they spend 3 hours a day or more watching television. Television use is almost universal, with only $2 \%$ of respondents indicating that they never watch television. Dutch-speaking respondents and boys tend to watch more television than their French-speaking and female counterparts.

\section{Time Effects}

$\mathrm{H} 1$ to be tested is whether spending more time watching television is associated with lower levels of political participation. To allow comparison of the effects of the various television measures, the analyses for the different 
TABLE 2

Time Spent Watching Television on an Average Weekday

\begin{tabular}{lccccc}
\hline & $\%$ & Girls & Boys & $\begin{array}{c}\text { French } \\
\text { speaking }\end{array}$ & $\begin{array}{c}\text { Dutch } \\
\text { speaking }\end{array}$ \\
\hline Never & 2.1 & 1.9 & 2.3 & 3.0 & 1.4 \\
$<1$ hour & 17.1 & 17.4 & 16.8 & 22.0 & 13.0 \\
$1-2$ hours & 44.5 & 45.6 & 43.6 & 45.6 & 43.6 \\
$3-4$ hours & 26.0 & 25.7 & 26.2 & 21.9 & 29.4 \\
$\geq 5$ hours & 10.3 & 9.4 & 11.1 & 7.5 & 12.7 \\
$M$ score & 3.25 & 3.23 & 3.27 & 3.09 & 3.39 \\
Total & 6,286 & 3,358 & 3,332 & 2,853 & 3,433 \\
\hline
\end{tabular}

Note. Entries are column percentages. Self-reported time spent watching television. Source: Belgian Youth Survey 2006 (Hooghe et al., 2006), $n=6,330$.

hypotheses are performed stepwise. In a first step we just enter time, followed by program preference in Step 2, and channel preference in Step 3. There is a negative significant effect (Table 3 ) between the time spent watching television and political consumerism and social movement engagement. For political engagement, the relation is not significant. Self-evidently, the observed relation between time and participation levels does not yet reveal the causal mechanism involved. Time replacement might be an obvious mechanism, but other attitudinal effects of heavy television viewing might play a role as well. With regard to the other variables, this analysis does not reveal many surprises. Political engagement is more common among those with high political interest and high levels of political knowledge, and boys outperform girls in this respect. For political consumerism, the gender balance is reversed, which is in line with the expectations derived from the literature. In addition, political interest and socioeconomic status have the strongest impact on the likelihood of using political consumerism as a form of participation, but some other control variables too remain significant. Social movement engagement, finally, is best predicted by gender (more girls than boys), political interest and socioeconomic status. It has to be noted that this model is most successful with an explained variance of $10.8 \%$.

\section{Program Preferences}

$\mathrm{H} 2$ assumes that entertainment programs will have a negative effect on engagement. As can be seen from Table 4, entertainment programs are most popular among the adolescent respondents, particularly movies, music programs, and sports programs. Only $10 \%$ of respondents, on the other hand, 
TABLE 3

Television and Political Participation

\begin{tabular}{|c|c|c|c|c|c|c|}
\hline & \multicolumn{2}{|c|}{$\begin{array}{c}\text { Political } \\
\text { engagement }\end{array}$} & \multicolumn{2}{|c|}{$\begin{array}{c}\text { Political } \\
\text { consumerism }\end{array}$} & \multicolumn{2}{|c|}{$\begin{array}{l}\text { Social movement } \\
\text { engagement }\end{array}$} \\
\hline & $\beta$ & $\Delta R^{2}$ & $\beta$ & $\Delta R^{2}$ & $\beta$ & $\Delta R^{2}$ \\
\hline Step 1 & & $0.061^{* * *}$ & & $0.084^{* * *}$ & & $0.108^{* * *}$ \\
\hline Gender & $-0.061^{* * *}$ & & $0.080^{* * *}$ & & $0.135^{* * *}$ & \\
\hline Citizenship status & $-0.013, n s$ & & $0.026^{*}$ & & $0.003, n s$ & \\
\hline Socioeconomic status & $0.006, n s$ & & $0.110^{* * *}$ & & $0.170^{* * *}$ & \\
\hline $\begin{array}{l}\text { Time spent watching } \\
\text { television }\end{array}$ & $-0.022, n s$ & & $-0.063^{* * *}$ & & $-0.075^{* * *}$ & \\
\hline Political knowledge & $0.071^{* * *}$ & & $0.059^{* * *}$ & & $0.075^{* * *}$ & \\
\hline Political interest & $0.201^{* * *}$ & & $0.182^{* * *}$ & & $0.137^{* * *}$ & \\
\hline Step 2 & & $0.012^{* * *}$ & & $0.005^{* * *}$ & & $0.005^{* * *}$ \\
\hline Entertainment preference & $-0.021, n s$ & & $-0.025, n s$ & & $0.023, n s$ & \\
\hline News preference & $0.103^{* * *}$ & & $0.067^{* * *}$ & & $0.058^{* * *}$ & \\
\hline Step 3 & & $0.003^{* * *}$ & & $0.004^{* * *}$ & & $0.002^{*}$ \\
\hline Public television & $-0.025, n s$ & & $0.062^{* * *}$ & & $0.006, n s$ & \\
\hline Commercial channels & $-0.051^{* * *}$ & & $-0.023, n s$ & & $-0.037^{* *}$ & \\
\hline Adjusted $R^{2}$ & \multicolumn{2}{|c|}{0.074} & \multicolumn{2}{|c|}{0.092} & \multicolumn{2}{|c|}{0.113} \\
\hline$F$ value & \multicolumn{2}{|c|}{$44.710^{* * *}$} & \multicolumn{2}{|c|}{$55.957^{* * *}$} & \multicolumn{2}{|c|}{$70.712^{* * *}$} \\
\hline
\end{tabular}

Note. Hierachical ordinary least squares regression. Entries are standardized coefficients and explained variance (for Steps 2 and 3: rise in explained variance). Source: Belgian Youth Survey 2006 (Hooghe et al., 2006).

${ }^{*} p<.05 .{ }^{* *} p<.01 .{ }^{* * *} p<.001$.

TABLE 4

Program Preferences

\begin{tabular}{llr}
\hline Preference & \multicolumn{1}{c}{ Program } & $\%$ \\
\hline Entertainment preference & Movies & 80.0 \\
& Music videos & 54.8 \\
& Sports programs & 27.1 \\
& Soap operas & 24.0 \\
& Cartoons & 18.1 \\
& Youth programs & 16.5 \\
& Reality TV & 12.5 \\
& Game shows & 11.8 \\
& Lifestyle programs & 10.7 \\
News preference & News and current events & 10.4 \\
Other programs (mixed content) & Talk shows & 5.7 \\
& Community shows & 1.1 \\
\hline
\end{tabular}

Note. Each respondent could indicate three types, so total \% is larger than 100 . The "other" program preferences do not load on one of the two dimensions. Source: Belgian Youth Survey 2006 (Hooghe et al., 2006). 
report a preference for news and current affairs programs. Although in itself a sobering consideration, this is also is a positive indicator of the quality of the responses. Whereas adult respondents systematically overestimate their preference for news broadcasts (Prior, 2009a), this seems less the case among adolescents. In reducing the scale of this information about program, we followed the method used by Prior (2007) by building an Entertainment Preference scale. Preferences for movies, music videos, sports programs, soap operas, cartoons, youth programs, reality TV, game shows, and lifestyle programs all loaded clearly on this scale. With these items a simple sum scale was constructing by adding the entertainment programs they preferred (up to three). A factor analysis of respondents' program preferences indicated that talk shows and local community shows did not load on this Entertainment Preference scale. This is not surprising, as such shows may contain both news and entertainment-related content. Neither, however, were they sufficiently correlated with a preference for news and current affairs, and therefore they were left out of the analysis. Aarts and Semetko (2003) succeeded in constructing one continuous scale, with entertainment preference and news preference as the two extremes. In the current data set, however, we encountered two different dimensions that could not be combined in one measure. Hence, two distinct dimensions had to be included, that is, an entertainment preference and a preference for news and current affairs. Both preferences could be summarized in a dummy variable $(0=$ no preference; $1=$ reference).

If both preferences are subsequently included in the analysis (Step 2 in Table 3), the results partly confirm $\mathrm{H} 2$ : There is a clear and significant positive relationship between a news preference and all three forms of political participation. Watching news and current affairs programs clearly boosts participation levels, and this effect remains significant, even after controlling for political interest and political knowledge (Table 3). Entertainment preference, on the other hand, does not have significant effects on any of the three types of participation. ${ }^{4}$ It has to be noted that including program preferences in the analysis does not substantially increase the explained variance of the models (although the difference is significant at the level of .001). Including the second step has the strongest effect on explained variance of the model for political engagement. The effect of television time and the control variables remains largely unchanged compared to the results reported in the first analysis (Step 1).

\footnotetext{
${ }^{4}$ Various other operationalizations of the entertainment preference scale have been tested, but none led to significant results in this analysis (results are available from the author).
} 


\section{Stations}

With regard to the distinction between public and commercial broadcasting, Belgium can be considered a typical European country, with a strong tradition of public broadcasting (Bardoel \& d'Haenens, 2008). It has to be remembered, however, that Belgium consists of two different communities: Although viewers in the Dutch-speaking community tend to watch Dutch-language channels, viewers in the French-speaking community obviously prefer French-language channels. In the questionnaire, respondents could select up to three channels (from a list of French or Dutch channels) they prefer to watch regularly. Within the Dutch community, $35 \%$ of respondents mentioned one of the VRT channels, the Flemish public broadcasting corporation. Within the French community, only $16 \%$ preferred its counterpart, RTBF. This is in line with what we know about the regular audience of both broadcasting corporations (Table 5). Both variables were measured by a dummy variable, expressing whether or not someone indicated watching public/commercial television.

Including the preference for commercial or public broadcasting allows us to develop full models, integrating the three dimensions we distinguished (Step 3 in Table 3). We can observe significant negative effects for a preference for commercial stations on political engagement and social movement engagement. In contrast, the effect of a preference for public television is significant only for political consumerism (Table 3). Taking channel preference into account, however, only has a very limited effect on the overall explained variance of the model.

To conclude, the models are most successful with regard to social movement engagement. Here we demonstrate a negative relation with television time and a preference for commercial stations. We also observe a positive

TABLE 5

Preference for Television Stations

\begin{tabular}{|c|c|c|c|c|}
\hline & Dutch community & $\%$ & French community & $\%$ \\
\hline Public television & $\begin{array}{l}\text { VRT (Een, Canvas, } \\
\text { Ketnet) }\end{array}$ & 35.1 & $\begin{array}{l}\text { RTBF (La Une, La } \\
\text { Deux) }\end{array}$ & 15.7 \\
\hline $\begin{array}{l}\text { Commercial } \\
\text { channels }\end{array}$ & $\begin{array}{l}\text { VTM, Kanaal2, } \\
\text { Vijftv, VT4, } \\
\text { Vitaya, Jim, TMF }\end{array}$ & 93.3 & $\begin{array}{l}\text { RTL-TVI, PLUG } \\
\text { TV, AB3, AB4, } \\
\text { MCM }\end{array}$ & 81.9 \\
\hline$N$ & & 3,248 & & 2,877 \\
\hline
\end{tabular}

Note. Preference for television channels in Belgian Youth Survey 2006 (Hooghe et al., 2006). Entries are column percentages. Note that respondents could indicate three channels, so that the total percentage may be more than 100 . 
relation, however, with news preference. The explained variance of the political consumerism model is lower. Here we also observe a negative effect of television time and a positive for news preference. Public broadcasting, too, is positively associated with political consumerism. Finally, explained variance is lowest for the political engagement variable. Here there is no effect of time, but we observe a positive effect of a news preference and a negative one for commercial stations.

\section{DISCUSSION AND CONCLUSION}

Despite the fact that not all relations proved to be equally significant, a clear pattern does emerge, allowing a partial confirmation of our three hypotheses. First, we observe a significant negative relation between television viewing time and two out of three participation types, which is in line with H1. Although most of the research on adults has failed to confirm the effect of television viewing time, this effect was clearly observed among this sample of adolescents. One explanation might be that, for adolescents, the average weekday is highly standardized. Because compulsory schooling is universal in Belgium, adolescents are typically at school from 8 a.m. to about 4 p.m. On weekdays, their leisure time is therefore concentrated between 4 p.m. and 10 p.m. During these hours, there is apparently a trade-off between time spent watching television and time spent on various forms of participation. Among adults, on the other hand, daily routines are much less standardized, suggesting that the competition between television and other forms of behavior might be less direct. ${ }^{5}$

With regard to program preference, $\mathrm{H} 2$ was partly confirmed, but in a slightly different direction than expected. We did not find much evidence for a negative impact of entertainment programs, but we did find evidence for a positive impact of a preference for news. Although the effect of an entertainment preference is usually negative or insignificant, a news preference is associated with higher levels of participation, and this is the only media use variable that is significantly related to all three forms of participation. In line with Prior's argument, this would suggest that the main problem for engagement and participation is not that citizens watch entertainment programs but rather that the time devoted to watching the news could be declining among some media audiences.

\footnotetext{
${ }^{5}$ One could argue that most adults also have a standardized daily routine, but this will mainly apply to those in full-time employment, which amounts to less than half of the adult population. Among late adolescents, on the other hand, about $98 \%$ participates in full-time schooling.
} 
For $\mathrm{H} 3$, results are similar. Although a preference for commercial stations was negatively related to two forms of participation, we observed a positive relation between public broadcasting and the third form of participation.

The current analysis builds on a number of previous studies, but at the same time it has a number of specific characteristics. With regard to validity, it should be mentioned that this analysis was based on a representative sample of adolescents in a European country with a strong tradition of public broadcasting. Previous studies have been conducted either among adults or among a highly selective sample of adolescents. A first, sobering finding for this age group is that information viewing is clearly not the main activity. When questioned about their program preferences, only some $10 \%$ of respondents mention news and current affairs programs. This does not mean they never watch television news: Most schools will try to encourage the habit of watching the television news in one way or another, but this is clearly not the adolescents' first preference. Their viewing habits seem largely determined by a preference for entertainment programs that is clearly stronger than the preference for information. Adolescents also prefer commercial stations, which are mentioned almost 3 times as often as public stations. Given these limitations, however, we can observe that the current study supports most of the hypotheses, although the observed relations are sometimes a little different than originally expected. We can conclude that regular viewers participate less often, although there seems to be a positive relation between political participation and both a news preference and a preference for public broadcasting. Thus, the negative assumptions about the impact of television viewing are more strongly confirmed than in most of the research among adults. Including all the other components of television watching, we still find that television time as such has a significant negative impact on participation levels. Although a news preference has a strong positive effect on participation, it should be noted that studies by Prior (2007) have shown that the percentage of viewers who regularly watch news broadcasts has steadily declined, possibly weakening this effect at an aggregate level. Self-evidently, this does not yet entail any claim about causality. We can assume that exposure to television content is selective: Viewers who are not interested in politics and/or public affairs will be less inclined to expose themselves to political information, and they are clearly also less likely to participate in political life. Whether or not the exposure to media content has additional effects on participation is a research question that can only be answered satisfactorily by relying on panel data.

Given the current state of research, it remains unclear what this implies for the general claim about the impact of television on political participation. On one hand, it could be argued that adolescents are a very specific 
group. Their agency options are much more restricted than is the case among adults: Their days are heavily scheduled by school requirements, and they are also less autonomous in how they spend their leisure time (e.g., with regard to mobility or finances). Simply watching television, therefore, might not always be a real choice for this group, but it could also serve as a default option if other preferred activities cannot be pursued. An optimistic assumption (which runs counter to the evidence presented by Prior, however) could be that as this group progresses in the life cycle, their program preferences will diversify, gradually including more news and current affairs programs than is the case in this cross-sectional observation.

On the other hand, it must be noted that participation patterns tend to be established quite early in the life cycle. Individuals who are already active at age 16 generally continue to be involved when they grow older (Hooghe, 2004). The fact that the negative relation between television and participation can already be observed at this age could therefore imply more negative long-term consequences for participation levels. The current data do not allow us to disentangle these long-term consequences, as this would require panel survey data that are not currently available, or at least not for this age group. But what this study among adolescents demonstrates is that there might be more reasons for concern than is acknowledged in most of the current literature. Although it might be true that television watching should be considered a multidimensional phenomenon, and that programs and stations do have specific content and effects, the overall negative relation between watching television and participation levels can be clearly established among adolescents. Preferences for news and for public broadcasting partly mitigate this negative relation, but they fail to fully compensate for it.

\section{REFERENCES}

Aalberg, T., Van Aelst, P., \& Curran, J. (2010). Media systems and the political information environment: A cross-national comparison. International Journal of Press/Politics. Advance online publication. doi: $10.1177 / 1940161210367422$

Aarts, K., \& Semetko, H. A. (2003). The divided electorate: Media use and political involvement. Journal of Politics, 65, 759-784.

Arnett, J. (1995). Adolescents' uses of media for self-socialization. Journal of Youth and Adolescence, 24, 519-533.

Austin, E. W., Van de Vord, R., Pinkleton, B. E., \& Epstein, E. (2008). Celebrity endorsements and their potential to motivate young voters. Mass Communication and Society, 11, 420-436.

Bardoel, J., \& d'Haenens, L. (2008). Public service broadcasting in converging media modalities. Convergence, 14, 351-360.

Blumler, J. G., \& Hoffmann-Riem, W. (1992). New roles for public television in Western Europe: Challenges and prospects. Journal of Communication, 42(1), 20-35. 
Cappella, J., \& Jamieson, K. H. (1997). Spiral of cynicism. The press and the public good. New York, NY: Oxford University Press.

Chaffee, S., \& Frank, S. (1996). How Americans get political information: Print versus broadcast news. Annals of the American Academy of Political and Social Science, 546, 48-58.

Dalton, R. (2005). Citizen politics. Public opinion and political parties in advanced industrial democracies (4th ed.). Washington, DC: CQ Press.

Delli Carpini, M., \& Keeter, S. (1996). What Americans know about politics and why it matters. New Haven, CT: Yale University Press.

De Vreese, C., \& Boomgaarden, H. (2006). News, Political knowledge and participation: The differential effects of news media exposure on political knowledge and participation. Acta Politica, 41, 317-341.

Eastman, S., \& Ferguson, D. (1997). Broadcast/cable programming. Strategies and practices. Belmont, CA: Wadsworth.

Fuchs, Th., \& Wößmann, L. (2007). What accounts for international differences in student performance? A re-examination using PISA data. Empirical Economics, 32, 433-464.

Gerbner, G., Gross, L., Morgan, M., \& Signorielli, N. (1980). The mainstreaming of America: Violence profile no 11. Journal of Communication, 30(3), 10-29.

Hess, R., \& Torney, J. (1967). The development of political attitudes in children. Chicago, IL: Aldine.

Ho, S. S., Binder, A. R., Becker, A. B., Moy, P., Scheufele, D. A., Brossard, D., et al. (2011). The role of perceptions of media bias in general and issue-specific political participation. Mass Communication and Society, 14, 343-374.

Hoffman, L., \& Thomson, T. (2009). The effect of television viewing on adolescents' civic participation: Political efficacy as a mediating mechanism. Journal of Broadcasting and Electronic Media, 53(1), 3-21.

Holtz-Bacha, C. (1990). Videomalaise revisited: Media exposure and political alienation in West Germany. European Journal of Communication, 5(1), 73-85.

Holtz-Bacha, C., \& Norris, P. (2001). "To entertain, inform and educate": Still the role of public television. Political Communication, 18, 123-140.

Hooghe, M. (2002). Watching television and civic engagement. Disentangling the effects of time, programs, and stations. Harvard International Journal of Press/Politics, 7, 84-104.

Hooghe, M. (2004). Political socialization and the future of politics. Acta Politica, 39, 331-341.

Hooghe, M., Quintelier, E., Claes, E., \& Dejaeghere, Y. (2006). Technical report of the Belgian Youth Survey. Leuven, Belgium: University of Leuven.

Jeffres, L. (1978). Cable TV and interest maximation. Journalism Quarterly, 55(1), 149-154.

Jennings, M. K., \& Stoker, L. (2004). Social trust and civic engagement across time and generations. Acta Politica, 39, 342-379.

Jenssen, A. T. (2009). Does public broadcasting make a difference? Political knowledge and electoral campaigns on television. Scandinavian Political Studies, 32, 247-271.

Jung, N., Kim, Y., \& Homero, G. (2011). The mediating role of knowledge and efficacy in the effects of communication on political participation. Mass Communication and Society, 14, 407-430.

Kim, E., Scheufele, D., \& Han, J. Y. (2011). Structure or predisposition? Exploring the interaction effect of discussion orientation and discussion heterogeneity on political participation. Mass Communication and Society, 14, 502-526.

Kim, Y. M., \& Vishak, J. (2008). Just laugh! You don't need to remember: The effects of entertainment media on political information acquisition and information processing in political judgment. Journal of Communication, 58, 338-360.

Kimberlee, R. H. (2002). Why don't British young people vote at general elections? Journal of Youth Studies, 5(1), 85-98. 
Larson, R. W. (2001). How U.S. children and adolescents spend time: What it does (and doesn't) tell us about their development. Current Directions in Psychological Science, 10, $160-164$.

Li, Y., \& Marsh, D. (2008). New Forms of political participation. Searching for expert citizens and everyday makers. British Journal of Political Science, 38, 247-272.

Livingstone, S. (2002). Young people and new media: Childhood and the changing media environment. London, UK: Sage.

Livingstone, S., \& Markham, T. (2008). The contribution of media consumption to civic participation. British Journal of Sociology, 59, 351-371.

Mendelsohn, M., \& Nadeau, R. (1996). The magnification and minimization of social cleavages by the broadcast and narrowcast news media. International Journal of Public Opinion Research, 8, 374-389.

Milbrath, L. W. (1965). Political participation. How and why do people get involved in politics? Chicago, IL: Rand McNally.

Milner, H. (2005). Are young Canadians becoming political dropouts? A comparative perspective. IRPP Choices, 11(3), 2-24.

Morris, J., \& Forgette, R. (2007). News grazers, television news, political knowledge, and engagement. Harvard International Journal of Press/Politics, 12(1), 91-107.

Moy, P., McCluskey, M., McCoy, K., \& Spratt, M. (2004). Political correlates of local news-media use. Journal of Communication, 54, 532-546.

Moy, P., Scheufele, D. A., \& Holbert, R. L. (1999). Television use and social capital: Testing Putnam's time displacement hypothesis. Mass Communication \& Society, 2(1/2), 27-45.

Newton, K. (1999). Mass media effects: Mobilization or media malaise? British Journal of Political Science, 29, 577-599.

Norris, P. (1996). Does television erode social capital? A reply to Putnam. PS: Political Science and Politics, 29, 474-480.

Norris, P. (2000a). The impact of television on civic malaise. In S. Pharr \& R. D. Putnam (Eds.), Disaffected democracies. What's troubling the trilateral countries? (pp. 231-251). Princeton, NJ: Princeton University Press.

Norris, P. (2000b). A virtuous circle: Political communications in postindustrial societies. Cambridge, UK: Cambridge University Press.

O'Toole, T., Lister, M., Marsh, D., Jones, S., \& McDonagh, A. (2003). Tuning out or left out? Participation and non-participation among young people. Contemporary Politics, 9(1), 45-61.

Parry, G., Moyser, G., \& Day, N. (1992). Political participation and democracy in Britain. Cambridge, UK: Cambridge University Press.

Pasek, J., Kenski, K., Romer, D., \& Jamieson, K. H. (2006). America's youth and community engagement. How use of mass media is related to civic activity and political awareness in 14to 22-year-olds. Communication Research, 33, 115-135.

Patterson, T. (1993). Out of order. New York, NY: Knopf.

Postman, N. (1985). Amusing ourselves to death. Public discourse in the age of showbusiness. New York, NY: Viking.

Prior, M. (2005). News v. entertainment: How increasing media choice widens gaps in political knowledge and turnout. American Journal of Political Science, 49, 594-609.

Prior, M. (2007). Post-broadcast democracy. How media choice increases inequality in political involvement and polarizes elections. Cambridge, UK: Cambridge University Press.

Prior, M. (2009a). The immensely inflated news audience: Assessing bias in self-reported news exposure. Public Opinion Quarterly, 73(1), 130-143.

Prior, M. (2009b). Improving media effects research through better measurement of news exposure. Journal of Politics, 71, 893-908. 
Putnam, R. D. (2000). Bowling alone. The collapse and revival of American Democracy. New York, NY: Simon \& Schuster.

Quintelier, E., \& Vissers, S. (2008). The effect of Internet use on political participation. An analysis of survey results for 16 year olds in Belgium. Social Science Computer Review, 26, 411-427.

Rosenstone, S., \& Hansen, M. (1993). Mobilization, participation, and democracy in America. New York, NY: Macmillan.

Rubin, A. (1983). Television uses and gratifications. The interactions of viewing patterns and motivations. Journal of Broadcasting and Electronic Media, 27(1), 37-51.

Ruggiero, T. (2000). Uses and gratifications theory in the 21 st century. Mass Communication \& Society, 3(1), 3-37.

Schmitt-Beck, R. (2008). Mass media and social capital in Europe: Evidence from multi-level analyses. In H. Meulemann (Ed.), Social capital in Europe: Similarity of countries and diversity of people? Multi-level analyses of the European Social Survey 2002 (pp. 159-187). Boston, MA: Brill.

Shah, D. V., McLeod, J. M., \& Yoon, S.-H. (2001). Communication, context, and community: An Exploration of print, broadcast, and Internet influences. Communication Research, 28, 464-506.

Sotirovic, M., \& McLeod, J. M. (2001). Values, communication behavior, and political participation. Political Communication, 18, 273-300.

Stolle, D., Hooghe, M., \& Micheletti, M. (2005). Politics in the supermarket. Political consumerism as a form of political participation. International Political Science Review, 26, 245-270.

Torney-Purta, J., Barber, C., \& Richardson, W. (2004). Trust in government-related institutions and political engagement among adolescents in six countries. Acta Politica, 39, 380-406.

Torney-Purta, J., Lehmann, R., Oswald, H., \& Schulz, W. (2001). Citizenship and education in twenty-eight countries: civic knowledge and engagement at age fourteen. Amsterdam: IEA.

Uslaner, E. M. (1998). Social capital, television, and the 'mean world': Trust, optimism, and civic participation. Political Psychology, 19, 441-467.

Verba, S., \& Nie, N. (1972). Participation in America. Political democracy and social equality. Chicago, IL: University of Chicago Press.

Verba, S., Schlozman, K. L., \& Brady, H. (1995). Voice and equality: civic voluntarism in American Politics. Cambridge, MA: Harvard University Press.

Vincent, R. C., \& Basil, M. D. (1997). College students' news gratifications, media use, and current events knowledge. Journal of Broadcasting \& Electronic Media, 41, 380-392.

Wattenberg, M. P. (2007). Is voting for young people? With a postscript on citizen engagement. New York, NY: Pearson Longman.

Zhang, W., \& Chia, S. W. (2006). The effects of mass media use and social capital on civic and political participation. Communication Studies, 57, 277-297.

Zukin, C., Keeter, S., Andolina, M., Jenkins, K., \& Delli Carpini, M. (2006). A new engagement? Political participation, civic life, and the changing American citizen. New York, NY: Oxford University Press. 


\section{APPENDIX: DESCRIPTIVES}

\begin{tabular}{lrrrcc}
\hline & Missing & $M$ & $S D$ & Minimum & Maximum \\
\hline Television viewing & 44 & 3.253 & 0.929 & 1 & 5 \\
Gender $(0=$ male, $1=$ female) & 8 & 0.531 & 0.499 & 0 & 1 \\
Citizenship status $(1=$ yes $)$ & 20 & 0.937 & 0.244 & 0 & 1 \\
Socioeconomic status & 491 & 0.000 & 1.000 & -2.774 & 1.941 \\
Political knowledge & 0 & 2.673 & 2.874 & 0 & 10 \\
Political interest & 55 & 1.981 & 0.794 & 1 & 4 \\
Political participation & 347 & 0.000 & 1.000 & -0.835 & 12.759 \\
Political consumerism & 347 & 0.000 & 1.000 & -2.327 & 5.404 \\
Civic participation & 347 & 0.000 & 1.000 & -1.737 & 5.472 \\
Music videos & 53 & 0.548 & 0.498 & 0 & 1 \\
Reality TV & 54 & 0.125 & 0.331 & 0 & 1 \\
Cartoons & 55 & 0.181 & 0.385 & 0 & 1 \\
Movies & 51 & 0.800 & 0.400 & 0 & 1 \\
Youth programs & 54 & 0.165 & 0.371 & 0 & 1 \\
Soap operas & 55 & 0.240 & 0.427 & 0 & 1 \\
Talk shows & 55 & 0.057 & 0.231 & 0 & 1 \\
News and current events & 54 & 0.104 & 0.306 & 0 & 1 \\
Game shows & 54 & 0.118 & 0.323 & 0 & 1 \\
Community shows & 55 & 0.011 & 0.104 & 0 & 1 \\
Lifestyle programs & 55 & 0.107 & 0.309 & 0 & 1 \\
Sports programs & 56 & 0.271 & 0.445 & 0 & 1 \\
Entertainment preference & 56 & 0.875 & .3305 & 0 & 1 \\
News preference & 54 & 0.104 & 0.306 & 0 & 1 \\
Public broadcasting & 65 & 0.263 & 0.440 & 0 & 1 \\
Commercial stations & 65 & 0.882 & 0.323 & 0 & 1 \\
\hline
\end{tabular}

